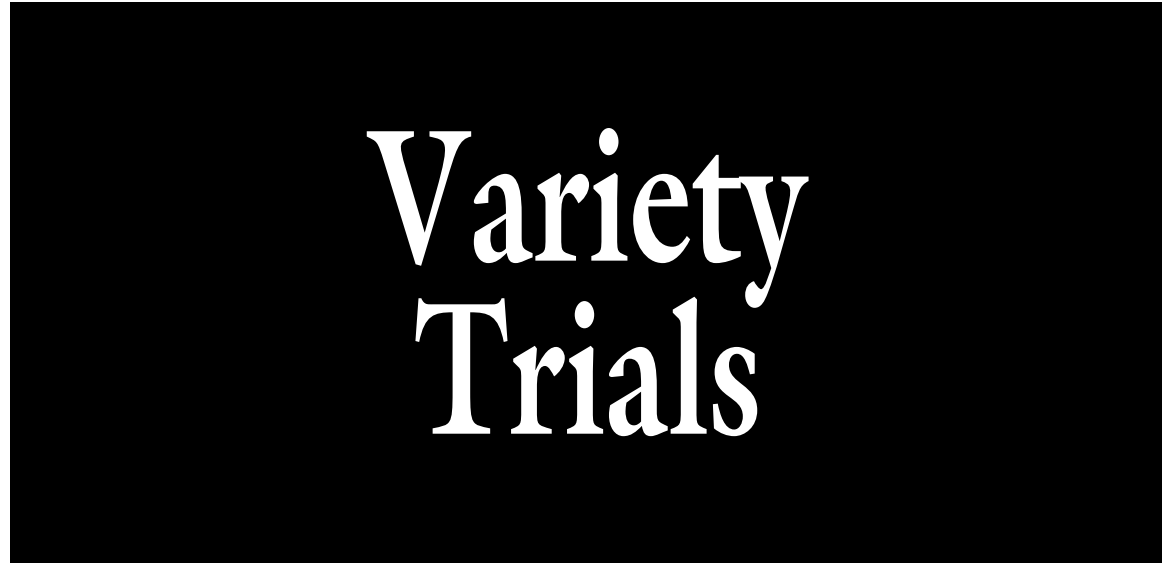

\section{Performance of Sweetpotato Cultivars Grown Using Biodegradable Black Plastic Mulch in New Hampshire}

\author{
Rebecca G. Sideman ${ }^{1}$
}

AdDITIONAL INDEX wORDs. Ipomoea batatas, yields, marketable, roots, varieties, New England

Summary. We evaluated the performance of several sweetpotato (Ipomoea batatas) cultivars grown on raised beds covered with biodegradable black mulch in New Hampshire. Six cultivars were evaluated over 4 years, and an additional four cultivars were evaluated in $\mathbf{2}$ or 3 years. Cultivars showed significant differences in marketable yield, percent cull, and percent small roots. The cultivars Covington and B94-14 Beauregard consistently produced high yields, whereas Vardaman consistently produced the lowest yields. 'Georgia Jet' exhibited variable performance, with marketable yields among the highest in 1 year and the lowest in another, largely because of a high percentage of cull roots due to severe cracking. Yields measured in our study compare favorably with average U.S. yields, with several cultivars producing over 40050 - 1 b bushels/acre in all years in which they were grown. In a 2 -year study with the cultivar Beauregard, biodegradable mulch increased overall yields (marketable, cull, and small roots) as compared with bare ground production on raised beds. However, the percentage of culled roots was higher in mulch treatments, primarily due to breakage during digging, and the observed increases in marketable yields were not statistically significant.

$\mathrm{S}$ weetpotato is a tropical crop best grown in regions that have frostfree growing periods of at least

Department of Biological Sciences, University of New Hampshire, 38 Academic Way, Durham, NH 03824

Partial funding was provided by the New Hampshire Vegetable and Berry Growers' Association, the New England Vegetable and Berry Growers' Association, and the New Hampshire Agricultural Experiment Station. This is Scientific Contribution Number 2594. This work was supported by the USDA National Institute of Food and Agriculture Hatch Project $\mathrm{NH} 00586$.

I am grateful to the farm, greenhouse, and technical staff at the University of New Hampshire for technical assistance and support, and also thankful to K. Pecota, O. Saunders, and N. Warren for providing thoughtful reviews for this article. I appreciate the advice and collaboration of the National Sweetpotato Collaborator's Group.

${ }^{1}$ Corresponding author. E-mail: becky.sideman@unh. edu.
4 to 6 months (Lebot, 2008). Accordingly, commercial production of sweetpotatoes in the United States occurs primarily in warm regions, with over 93\% of production taking place in North Carolina, Mississippi, California, Louisiana, and Florida [U.S. Department of Agriculture (USDA), 2015].
With very few exceptions, sweetpotato production in sites with relatively short growing seasons is not described in the peer-reviewed literature. Hochmuth and Howell (1983) demonstrated yields of up to $18.6 \mathrm{Mg} \cdot \mathrm{ha}^{-1}$ (332 50 -lb bushels/acre) using the cultivar Jewel on raised beds with black plastic mulch in Massachusetts. This study was conducted before the release of several currently important cultivars, including Beauregard (Rolston et al., 1987) and Covington (Yencho et al., 2008). More recent extension publications show that high yields are possible in cold climates, for example, Hill (2001) evaluated seven different cultivars in Connecticut using flat beds covered with black plastic mulch, and reported yields of up to $32.5 \mathrm{Mg} \cdot \mathrm{ha}^{-1}$ (580 50-lb bushels/ acre). According to Filotas (2012), several cultivars have also performed well in southwestern Ontario. As a result, there is a need for a comprehensive evaluation of currently available cultivars in colder climates.

Since 2007, sweetpotato acreage throughout the New England states has increased more than 8 -fold from 4 to 33 acres, all for fresh-market sales (USDA, 2014), with most individual producers having small plantings of less than $1 / 2$ acre. In New England, it is typical for growers to use several season extension strategies. First, planting stock is typically purchased from slip producers in U.S. southern states and is shipped to U.S. northern growers. Black biodegradable or standard plastic mulch is frequently used to warm the soil surface and for weed control. In addition, some growers use raised beds to increase early-season soil warming.

Drawbacks coupled with the use of plastic mulches include increased labor, equipment, and costs associated with their removal and disposal at the end of the growing season. Starchbased biodegradable mulches present a possible solution to these problems. In several studies using warm season

\begin{tabular}{lllc}
\hline $\begin{array}{l}\text { Units } \\
\begin{array}{l}\text { To convert U.S. to SI, } \\
\text { multiply by }\end{array}\end{array}$ & U.S. unit & SI unit & $\begin{array}{l}\text { To convert SI to U.S., } \\
\text { multiply by }\end{array}$ \\
\hline 0.4047 & $\mathrm{acre}(\mathrm{s})$ & $\mathrm{ha}$ & 2.4711 \\
0.3048 & $\mathrm{ft}$ & $\mathrm{m}$ & 3.2808 \\
2.54 & inch $(\mathrm{es})$ & $\mathrm{cm}$ & 0.3937 \\
0.4536 & $\mathrm{lb}$ & $\mathrm{kg}$ & 2.2046 \\
1.1209 & $\mathrm{lb} / \mathrm{acre}$ & $\mathrm{kg} \cdot \mathrm{ha}^{-1}$ & 0.8922 \\
0.0254 & $\mathrm{mil}$ & $\mathrm{mm}$ & 39.3701 \\
2.2417 & ton $(\mathrm{s}) / \mathrm{acre}$ & $\mathrm{Mg} \cdot \mathrm{ha}^{-1}$ & 0.4461 \\
$\left({ }^{\circ} \mathrm{F}-32\right) \div 1.8$ & ${ }^{\circ} \mathrm{F}$ & ${ }^{\circ} \mathrm{C}$ & $\left({ }^{\circ} \mathrm{C} \times 1.8\right)+32$
\end{tabular}


vegetable crops, starch-based black biodegradable mulches have shown similar positive effects on plant growth as black polyethylene mulch (Cowan et al., 2014; Miles et al., 2012; Waterer, 2010). Sweetpotato is particularly well-suited to the use of biodegradable mulches that break down during the growing season and do not need to be removed like standard polyethylene mulches. Before harvest, vines are typically mowed with a rotary mower, which usually results in some shredding of the plastic mulch. With conventional plastic, this adds fragments to the soil that cannot be removed, whereas it merely speeds breakdown for biodegradable plastics.

The positive impact of plastic mulches on growth of several warm season crops has been demonstrated (Lamont, 2005), but the effects of mulches on sweetpotato yields have received little research attention. In Massachusetts, Hochmuth and Howell (1983) used black plastic mulch, but did not evaluate this practice as compared with bare ground production. In Connecticut, Hill (2001) compared hilled and flat beds, with and without black plastic mulch. Although hilling beds did not result in higher yields, black plastic increased yields in some, but not all, experiments. In Alabama, Brown et al. (1998) found that black plastic mulch in combination with rowcover or row tunnels, but not on its own, increased sweetpotato yields as compared with those grown on bare ground. Because of the widespread use of plastic mulch in the northeastern United States, evaluation of the efficacy of this practice using currently available cultivars is warranted.

In 2005, we began evaluating sweetpotato cultivars in New Hampshire, and selected those that performed well in initial experiments for further assessment. Between 2008 and 2013, we participated in the National Sweetpotato Collaborators' Group evaluations. Our objectives were to evaluate the performance of several sweetpotato cultivars for production and direct marketing in New England, and to compare yields when using biodegradable mulch as compared with bare ground. In this article, we describe the results of our experiments evaluating eight cultivars grown on black biodegradable mulch over 4 years in New Hampshire, and comparing mulch and bare ground treatments for the cultivar Beauregard over 2 years.

\section{Methods}

All experiments were conducted at the University of New Hampshire Woodman Horticultural Research Farm, in Durham, $\mathrm{NH}$ (lat. $43^{\circ} 15^{\prime} \mathrm{N}$, long. $\left.70^{\circ} 94^{\prime} \mathrm{W}\right)$. The four experiments were conducted in two adjacent fields, both with Charlton fine sandy loam (coarse loamy, mixed, active, mesic Typic Dystrudepts) (USDA, 2013). Monthly temperature and precipitation data were obtained from the National Climatic Data Center (NCDC) for Durham, $\mathrm{NH}$ [Station 272174 (lat. $43^{\circ} 14^{\prime} \mathrm{N}$, long. $\left.\left.70^{\circ} 95^{\prime} \mathrm{W}\right)\right]$.

Sweetpotato slips were obtained from several suppliers (Table 1). Six cultivars were evaluated in all 4 years. The four remaining cultivars were evaluated in 2 or 3 years, based on availability from commercial sources. For 'Covington' (Yencho et al., 2008) and an improved clone of 'Beauregard', 'B94-14' (Bryan et al., 2003), second generation (G-2) planting stock was provided by K. Pecota [North Carolina State University, Raleigh (NCSU)] in all 4 years. All other slips were obtained from commercial sources. For ' $\mathrm{Cov}$ ington' and 'Beauregard', results are presented separately for slips from NCSU and commercial sources. In 2008 and 2009, all cultivars were obtained from Steele Plant Co. (Gleason, TN). In 2010, all cultivars were obtained from Steele Plant Co. except for Carolina Ruby, Covington, GA Jet, and Vardaman, which were obtained from George's Plant Farm (Martin, TN). In 2013, all cultivars were obtained from Scott Farms (Lucama, NC) except for Georgia Jet and White Yam, which were obtained from George's Plant Farm. Except for two white-fleshed cultivars, O'Henry and White Yam, all other cultivars were orange-fleshed.

A combination bed former and mulch layer was used to create raised beds 36-inches wide covered with 0.6mil-thick black biodegradable plastic mulch (Biotelo; Dubois Agrinovation, Waterford, ON, Canada). Distance between bed centers was $6 \mathrm{ft}$. A single line of drip irrigation tape (T-Tape; T Systems International, San Diego, CA) was laid under plastic on each row. For the experiment comparing mulch treatments, beds were formed and covered with plastic, and plastic was immediately removed from the bare plots. Slips were spaced 9-inches apart in a single row on raised beds and were transplanted on 20 June 2008, 20 June 2009, 11 June 2010, and 12 June 2013. All experiments used replicated randomized complete block designs with four replicates of 25 plants per experimental unit.

Before bed preparation, $25 \mathrm{lb} /$ acre nitrogen $(\mathrm{N})$ and $166 \mathrm{lb} / \mathrm{acre}$ potassium $(\mathrm{K})$ were incorporated preplant, based on soil test recommendations; the rate was the same in all four experiments. In 2008 and 2009, plants were fertigated twice during the growing season with $5 \mathrm{lb} /$ acre $\mathrm{N}$ in the form of calcium nitrate $\left[\mathrm{CaNO}_{3}(15.5 \mathrm{~N}-\right.$ $0 \mathrm{P}-0 \mathrm{~K})]$. In 2010 and 2013, plants received no supplemental fertilizer during the growing season. Plants were drip irrigated as needed throughout the growing season, depending on precipitation.

Sweetpotatoes were harvested before the first hard fall frost, on 2 Oct. 2008,9 Oct. 2009, 30 Sept. 2010, and 16 Oct. 2013, which corresponded to $104,111,111$, and $126 \mathrm{~d}$ after transplanting. Vines were removed with a rotary mower, and roots were hand lifted with forks. Roots were left to dry on top of raised beds until the following day, when they were graded, sorted, weighed, and removed from the field.

Roots were sorted into the following categories: marketable (root diameter at least 1.5 inch with no major defects that would reduce storage life), cull (roots of any size that exhibited wounds, breakage, or severe cracking that would reduce storage life), undersized (small roots with diameter less than $\mathbf{1 . 5}$ inches, that did not fall into the cull category). The marketable category in this modified rating system corresponds with the U.S. standard No. 1 and No. 2 categories (USDA, 2005). Total yields equal marketable plus cull plus undersized roots. Roots were counted and weighed, and data were subjected to analysis of variance (ANOVA) using JMP Pro 11 (SAS Institute, Cary, NC). Initially, data for the six cultivars that were grown in all 4 years were analyzed using ANOVA. Because significant cultivar $\times$ year interactions existed, data from each year were analyzed and presented separately. When comparing cultivars, when the overall $\mathrm{F}$ test was significant $(P \leq 0.05)$, 
differences between treatments were evaluated using Tukey's honestly significant difference tests at the $P \leq 0.05$ level.

\section{Results}

Monthly precipitation and mean temperatures are shown alongside 30-year averages for Durham, $\mathrm{NH}$ in Table 2. These were presented to show whether the experimental period deviated from typical conditions, and to provide perspective for those growing in other regions with short growing seasons. On the whole, 2008 and 2013 were wetter than normal, because of more rainfall during the early part of the season (July 2008 and June 2013). The 2010 season was slightly drier than normal, primarily due to low rainfall in September. In general, temperatures were typical, with 2009 slightly cooler and 2013 slightly warmer than normal.
Marketable yield of the highestyielding sweetpotato cultivars ranged from 503 to 887 of 50 -lb bushels / acre, whereas the lowest-yielding cultivar produced as little as 74 bushels/ acre in 1 year. In all 4 years, 'Covington' and 'B94-14 Beauregard' either produced the highest yields of marketable roots or produced yields not significantly different from the highest-yielding cultivar (Table 1). In addition, 'Georgia Jet', 'Japanese', and 'O'Henry' (2008)

Table 1. Mean yield of marketable roots per plant for sweetpotato cultivars grown in 4 years in Durham, NH.

\begin{tabular}{|c|c|c|c|c|c|c|}
\hline \multirow[b]{2}{*}{ Cultivar } & \multirow[b]{2}{*}{ Skin/flesh color } & \multirow[b]{2}{*}{ Source $^{\mathrm{z}}$} & \multicolumn{4}{|c|}{ Marketable yield (bushels/acre) } \\
\hline & & & 2008 & 2009 & 2010 & 2013 \\
\hline B94-14 Beauregard & Copper/orange & NCSU & $470 \mathrm{ab}^{\mathrm{x}}$ & $542 \mathrm{a}$ & $887 \mathrm{a}$ & $492 \mathrm{ab}$ \\
\hline Carolina Ruby & Red/orange & $\mathrm{ST} / \mathrm{G} / \mathrm{SC}$ & - & - & $467 \mathrm{bc}$ & $401 \mathrm{ab}$ \\
\hline Covington & Copper/orange & NCSU & $503 \mathrm{a}$ & $405 \mathrm{ab}$ & $654 \mathrm{ab}$ & $587 \mathrm{a}$ \\
\hline Covington & Copper/orange & $\mathrm{G} / \mathrm{SC}$ & - & - & $747 a$ & $418 \mathrm{ab}$ \\
\hline O’Henry & Light tan/white & $\mathrm{ST} / \mathrm{G}$ & $380 \mathrm{abc}$ & $246 \mathrm{bc}$ & $380 \mathrm{~cd}$ & $256 \mathrm{bc}$ \\
\hline Vardaman & Light orange/orange & $\mathrm{ST} / \mathrm{G}$ & $103 \mathrm{~d}$ & $93 \mathrm{c}$ & $167 \mathrm{~d}$ & - \\
\hline White Yam & Tan/white & $\mathrm{ST} / \mathrm{G}$ & $269 \mathrm{bcd}$ & $170 \mathrm{c}$ & $300 \mathrm{~cd}$ & $321 \mathrm{abc}$ \\
\hline
\end{tabular}

${ }^{2} \mathrm{NCSU}=$ North Carolina State University, Raleigh; ST = Steele Plant Co., Gleason, TN; G = George's Plant Farm, Martin, TN; SC = Scott Farms, Lucama, NC.

${ }^{y}$ Marketable roots had diameter at least 1.5 inches $(3.81 \mathrm{~cm})$ and lacked major defects that would reduce storage life; $150-\mathrm{lb}(22.7 \mathrm{~kg})$ bushel $/$ acre $=56.0426 \mathrm{~kg} \cdot \mathrm{ha}^{-1}$

${ }^{x}$ Within a column, means followed by the same letter are not significantly different at $P \leq 0.05$ ( $n=4$ replicates) using Tukey's honestly significant difference test.

Table 2. Monthly precipitation and mean temperatures in Durham, NH throughout the four growing seasons of 2008 , 2009,2010 , and 2013.

\begin{tabular}{|c|c|c|c|c|c|c|c|c|c|c|}
\hline \multirow[b]{2}{*}{ Month } & \multicolumn{5}{|c|}{ Precipitation (inches) ${ }^{\mathrm{z}}$} & \multicolumn{5}{|c|}{ Mean temp $\left({ }^{\circ} \mathbf{F}\right)^{\mathrm{z}}$} \\
\hline & 2008 & 2009 & 2010 & 2013 & Normaly $^{y}$ & 2008 & 2009 & 2010 & 2013 & Normal \\
\hline June & 3.1 & 4.8 & 3.1 & 9.0 & 3.9 & 67.1 & 63.1 & 60.7 & 67.1 & 65.8 \\
\hline Aug. & 4.1 & 3.3 & 4.5 & 3.1 & 3.8 & 66.4 & 72.1 & 70.5 & 69.1 & 69.3 \\
\hline Sept. & 8.4 & 1.7 & 1.1 & 7.1 & 4.4 & 62.1 & 59.9 & 65.5 & 62.1 & 61.5 \\
\hline Overall & 24.8 & 16.7 & 12.8 & 21.9 & 16.3 & 66.9 & 65.8 & 67.3 & 68.1 & 66.9 \\
\hline
\end{tabular}

${ }^{\mathrm{z}} \mathrm{l}$ inch $=2.54 \mathrm{~cm},\left({ }^{\circ} \mathrm{F}-32\right) \div 1.8={ }^{\circ} \mathrm{C}$.

${ }^{y}$ Normal refers to the 30-year average for 1981-2010, reported for Durham, NH by the U.S. Department of Commerce (2010).

Table 3. Mean percentage of culled and undersized roots for sweetpotato cultivars grown in 4 years in Durham, NH.

\begin{tabular}{|c|c|c|c|c|c|c|c|c|c|}
\hline \multirow[b]{2}{*}{ Cultivar } & \multirow[b]{2}{*}{ Source ${ }^{\mathrm{z}}$} & \multicolumn{2}{|c|}{2008} & \multicolumn{2}{|c|}{2009} & \multicolumn{2}{|c|}{2010} & \multicolumn{2}{|c|}{2013} \\
\hline & & $\begin{array}{c}\text { Mean } \\
\text { culls }(\%)^{y}\end{array}$ & $\begin{array}{c}\text { Mean } \\
\text { small (\%) }\end{array}$ & $\begin{array}{c}\text { Mean } \\
\text { culls (\%) }\end{array}$ & $\begin{array}{c}\text { Mean } \\
\text { small (\%) }\end{array}$ & $\begin{array}{c}\text { Mean } \\
\text { culls (\%) }\end{array}$ & $\begin{array}{c}\text { Mean } \\
\text { small (\%) }\end{array}$ & $\begin{array}{c}\text { Mean } \\
\text { culls (\%) }\end{array}$ & $\begin{array}{c}\text { Mean } \\
\text { small (\%) }\end{array}$ \\
\hline Beauregard & $\mathrm{ST} / \mathrm{SC}$ & $11 \mathrm{~b}$ & $29 \mathrm{~b}$ & $29 \mathrm{bc}$ & $9 \mathrm{c}$ & $25 \mathrm{ab}$ & $15 \mathrm{~b}$ & $17 \mathrm{~b}$ & $15 \mathrm{a}$ \\
\hline Carolina Ruby & $\mathrm{ST} / \mathrm{G} / \mathrm{SC}$ & - & - & - & - & $21 \mathrm{~b}$ & $15 \mathrm{~b}$ & $17 \mathrm{~b}$ & $20 a$ \\
\hline Covington & NCSU & $5 \mathrm{~b}$ & $14 \mathrm{~cd}$ & $10 \mathrm{c}$ & $8 \mathrm{c}$ & $7 \mathrm{~b}$ & $7 \mathrm{~b}$ & $7 \mathrm{~b}$ & $9 \mathrm{a}$ \\
\hline Japanese & $\mathrm{ST} / \mathrm{SC}$ & $25 \mathrm{ab}$ & $20 \mathrm{bc}$ & - & - & - & 一 & $12 \mathrm{~b}$ & $21 \mathrm{a}$ \\
\hline O’Henry & $\mathrm{ST} / \mathrm{G}$ & $14 \mathrm{ab}$ & $13 \mathrm{~cd}$ & $23 \mathrm{bc}$ & $14 \mathrm{bc}$ & $18 \mathrm{~b}$ & $14 \mathrm{~b}$ & $22 \mathrm{~b}$ & $18 \mathrm{a}$ \\
\hline Vardaman & $\mathrm{ST} / \mathrm{G}$ & $25 \mathrm{ab}$ & $42 \mathrm{a}$ & $35 \mathrm{~b}$ & $32 a$ & $16 \mathrm{~b}$ & $44 \mathrm{a}$ & - & - \\
\hline White Yam & $\mathrm{ST} / \mathrm{G}$ & $17 \mathrm{ab}$ & $29 \mathrm{~b}$ & $13 \mathrm{c}$ & $26 \mathrm{ab}$ & $8 \mathrm{~b}$ & $34 \mathrm{a}$ & $16 \mathrm{~b}$ & $25 \mathrm{a}$ \\
\hline
\end{tabular}

${ }^{2} \mathrm{NCSU}$ = North Carolina State University, Raleigh; ST = Steele Plant Co., Gleason, TN; G = George's Plant Farm, Martin, TN; SC = Scott Farms, Lucama NC. ${ }^{y}$ Culled roots were roots of any size that exhibited wounds, breakage, or severe cracking that would reduce storage life; undersized roots were undamaged roots with diameter less than 1.5 inches $(3.81 \mathrm{~cm})$.

${ }^{x}$ Within a column, means followed by the same letter are not significantly different at $P \leq 0.05$ ( $n=4$ replicates) using Tukey's honestly significant difference test. 
and 'Beauregard', 'Carolina Ruby', and 'White Yam' (2013) had yields similar to the highest yielding cultivar.

'Vardaman' consistently produced the lowest mean marketable yields in the 3 years in which it was grown $(2008$ to 2010). 'Georgia Jet' produced the lowest mean marketable yield in 2013, and was among the lowest yielding cultivars in 2009. 'White Yam' and significantly different from the lowestyielding cultivar in all years in which they were grown.

'Georgia Jet' consistently exhibited severe cracking, which resulted in the highest percentage of cull roots in all 4 years, ranging from $37 \%$ in 2008 to $69 \%$ in 2013 (Table 3). Other cultivars had moderate percentages of culled roots; percentages observed for 'Japanese', 'O'Henry', 'Vardaman', and 'White Yam' in 2008 and 'Beauregard' in 2010 were not significantly different from 'Georgia Jet'. The primary reason for culling roots in 'Georgia Jet' and 'White Yam' was cracking, whereas breakage of very long roots was the primary reason for culling roots of 'Beauregard', 'O'Henry', 'Japanese', 'Carolina Ruby', and 'Vardaman'. 'Covington' consistently showed the lowest percentage of culled roots in all experiments, though not significantly lower than several other cultivars.

'Vardaman' had the highest percentage of roots that were too small in the 3 years it was grown, ranging from $32 \%$ to $44 \%$ (Table 3). 'White Yam' also had a high percentage of small roots, not significantly different from 'Vardaman' in 2009 and 2010. In 2013, we did not observe significant 'Japanese' also produced yields not

differences among cultivars in percentage of small roots.

In all 4 years, the biodegradable mulch did break down during the growing season, generally after the vine canopy had covered the beds. We did not observe weed growth where the plastic had broken down, likely because surface weed seeds had already germinated and died shortly after the mulch had been laid. Some pieces of mulch were still evident at the end of the season.

The results of experiments designed to evaluate the effects of using biodegradable mulch for the cultivar Beauregard are shown in Table 4. Year had a significant effect on both mean marketable and total yields. The presence of mulch significantly increased the mean total yield and the percentage of culled roots in both years. There was a significant year $\times$ treatment interaction effect for percentage of small roots. The percentage of small roots was lower in mulch treatments than in bare ground in 2009, but not in 2010 (data not shown). Although mean marketable weight was greater in mulch treatments in both years, the difference was not statistically significant $(P=0.052)$.

\section{Discussion}

Our results show that sweetpotato can be a viable crop for growers in climates with short growing seasons. To our knowledge, this is the first report that describes the performance of modern sweetpotato cultivars in northern regions. Despite a relatively short growing season (104-126 d over the course of our experiments), the highest-yielding cultivars in each year

Table 4. Effects of black biodegradable plastic mulch on productivity of 'Beauregard' sweetpotato in Durham, NH.

\begin{tabular}{lcccc}
\hline Treatment & $\begin{array}{c}\text { Mean marketable } \\
\text { yield (bushels/acre) }\end{array}$ & $\begin{array}{c}\text { Mean total yield } \\
\text { (bushels/acre) }\end{array}$ & $\begin{array}{c}\text { Mean } \\
\text { culls (\%) }\end{array}$ & $\begin{array}{c}\text { Mean } \\
\text { small (\%) }\end{array}$ \\
\hline $\begin{array}{l}\text { Mulch } \\
\text { Present }\end{array}$ & $401 \mathrm{a}$ & & & \\
$\quad \begin{array}{l}\text { Absent } \\
\text { Year }\end{array}$ & $337 \mathrm{a}$ & $658 \mathrm{a}^{\mathrm{y}}$ & $26.7 \mathrm{a}$ & $12.0 \mathrm{~b}$ \\
2009 & $277 \mathrm{~b}$ & $470 \mathrm{~b}$ & $11.8 \mathrm{~b}$ & $17.9 \mathrm{a}$ \\
2010 & $463 \mathrm{a}$ & $442 \mathrm{~b}$ & 21.7 & 15.9 \\
$\begin{array}{l}\text { Significance } \\
\text { Mulch }\end{array}$ & & $685 \mathrm{a}$ & 16.9 & 14.0 \\
Year & $\mathrm{NS}$ & $* * *$ & $* *$ & $* *$ \\
Mulch $\times$ Year & $* * *$ & $* * *$ & $\mathrm{NS}$ & $\mathrm{NS}$ \\
\hline
\end{tabular}

${ }^{\mathrm{z}} 150-\mathrm{lb}(22.7 \mathrm{~kg})$ bushel $/$ acre $=56.0426 \mathrm{~kg} \cdot \mathrm{ha}^{-1}$.

${ }^{y}$ For each treatment, within a column, means followed by the same letter are not significantly different at $P \leq 0.05$ using the ANOVA F test.

${ }^{\text {ss }}$ o significant differences detected, ${ }^{* *} P<0.001,{ }^{* *} P<0.01$. produced marketable yields ranging from 503 to 887 bushels/acre. This compares favorably with national average yields, which range from 310 to 550 bushels/acre depending on the state, with an overall average of 438 bushels/acre (USDA, 2015).

High light intensity and long days have been shown to increase number of sweetpotato storage roots, whereas formation and development of storage roots is promoted by short days (Lebot, 2008). Comparing the northern latitude of New Hampshire with the southern latitudes of more traditional sweetpotato production areas, the combination of longer days during summer months that decrease at a more rapid rate during late summer may therefore, contribute to production of high yields despite a relatively short growing season.

Direct-market sales are the primary outlet for growers in our region, and locally grown sweetpotato can enhance growers' fall and winter offerings. Although typical orange-skinned and copper-fleshed cultivars (Covington, B94-14 Beauregard, and Beauregard) produced consistently high yields, several cultivars with novel skin and flesh colors, such as the red-skinned 'Carolina Ruby', the purple-skinned 'Japanese', and tan-skinned and whitefleshed 'O'Henry' also performed well. In our study, 'Covington', 'Carolina Ruby', and 'B94-14 Beauregard' produced over 400 bushels/acre in all years in which they were grown, and 'Beauregard', 'Japanese', and 'O'Henry' produced over 245 bushels/acre in all years in which they were grown. Although 'Georgia Jet' is frequently marketed specifically for growers in short growing seasons, our results suggest that a tendency to crack makes it unsuitable for commercial production. 'White Yam', which had a drier texture and less sweet taste than other cultivars we evaluated (data not shown), had a tendency to produce roots that are too small, suggesting that it may not reach its full yield potential in our growing conditions. Finally, although 'Vardaman' had excellent flavor and provided a novel and attractive light orange color, its tendency to produce long and slender roots that did not reach full size limited its yield potential and made it unsuitable for commercial production.

The source of planting stock may be an important factor in success. In 3 out of 4 years, we observed 
significantly higher yields for 'B94-14 Beauregard', which was grown from G-2 planting stock produced from virus-indexed plants, than for 'Beauregard' of unknown generation obtained from commercial sources. Although the reasons for this difference in our study are not known, several researchers have reported increases in yield by using planting stock produced from virus-tested plants (Bryan et al., 2003; La Bonte et al., 2004). Our results are consistent with these reports, and suggest that the use of clean planting stock should be encouraged to prevent spread of virus and maintain high yields.

Our observations of the effects of black biodegradable mulch on yields in sweetpotato are consistent with those reported for black polyethylene mulch by Hill (2001). Although biodegradable mulch increased yield potential (by consistently increasing overall yields), it increased the percentage of culled roots and we did not observe significant increases in marketable yields. With the cultivar Beauregard, most culled roots were long roots that spread beyond where the majority of roots were located, and were therefore, broken during hand digging. For different cultivars, such as those with shorter roots, it is possible that increases in marketable as well as total yield would be observed. It is also possible that using a mechanical lifter to loosen the roots would have reduced the percentage of cull roots. The current price of biodegradable mulch in our region is about $\$ 470 /$ acre, so even a very modest yield increase would outweigh this cost. Additional research, especially including other cultivars of interest, is needed to thoroughly evaluate the economic impacts of this practice.

Overall, the results of this study show that sweetpotato is a viable crop for New Hampshire as well as other northern states of United States. We recommend Beauregard and Covington as orange-fleshed cultivars that produce consistently high yields. Although slightly less consistent yields, 'Carolina Ruby', 'Japanese', and 'O'Henry' performed well and are recommended if specialty colors or textures are desired. Although the use of biodegradable plastic mulch did not significantly increase marketable yield in this study, the increases in overall yields suggest that increases in marketable yields may be possible in other sites or with other cultivars. Further, labor reductions through weed control may be enough incentive for some growers to use biodegradable mulch for sweetpotato production.

\section{Literature cited}

Brown, J.E., F.M. Woods, and C. ChannellButcher. 1998. Effect of black plastic mulch and row cover on sweet potato production. J. Veg. Crop Production 4(1):49-54.

Bryan, A.D., Z. Pesic-VanEsbroeck, J.R. Schultheis, K.V. Pecota, W.H. Swallow, and G.C. Yencho. 2003. Cultivar decline in sweetpotato: I. Impact of micropropagation on yield, storage root quality, and virus incidence in 'Beauregard'. J. Amer. Soc. Hort. Sci. 128:846-855.

Cowan, J.S., C.A. Miles, P.K. Andrews, and D.A. Inglis. 2014. Biodegradable mulch performed comparably to polyethylene in high tunnel tomato (Solanum lycopersicum L.) production. J. Sci. Food Agr. 94(9):1854-1864.

Filotas, M. 2012. Sweet potato varieties for Ontario. Ontario Ministry of Agriculture, Food and Rural Affairs. 25 Apr. 2012. <http://www.omafra.gov.on.ca/ english/crops/hort/news /hortmatt/ 2012/09hrtl2a5.htm>.

Hill, D.E. 2001. Specialty crops: Okra, leek, sweet potato and jilo. Connecticut Agr. Expt. Sta. Bul. 976.

Hochmuth, J.G. and J.C. Howell. 1983. Effect of black plastic mulch and raised beds on sweet potato growth and root yield in a northern region. HortScience 18:467468.

La Bonte, D., C. Clark, A. Villordon, J. Cannon, M. Hoy, M. Sistrunk, E. Freeman, and G. Roberts. 2004. Yield of four generations of virus-tested sweetpotato. HortTechnology 14:320-322.
Lamont, W. 2005. Plastics: Modifying the microclimate for the production of vegetable crops. HortTechnology 15:477-481.

Lebot, V. 2008. Crop production science in horticulture, Volume 17, Tropical root and tuber crops: Cassava, sweet potato, yams and aroids. CABI Publishing, Wallingford, UK.

Miles, C., R. Wallace, A. Wszelaki, J. Martin, J. Cowan, T. Walters, and D. Inglis. 2012. Deterioration of potentially biodegradable alternatives to black plastic mulch in three tomato production regions. HortScience 47:1270-1277.

Rolston, L.H., C.A. Clark, J.M. Cannon, W.M. Randle, E.G. Riley, P.W. Wilson, and M.L. Robbins. 1987. 'Beauregard' sweetpotato. HortScience 22:1338-1339.

U.S. Department of Agriculture. 2005. United States standards for grades of sweetpotato. 19 Feb. 2015. <http:// www.ams.usda.gov/AMSv1.0/getfile? $\mathrm{dDocName}=$ STELPRDC5050330 $>$.

U.S. Department of Agriculture. 2013. Official soil series descriptions. 27 Apr. 2015. <http://soils.usda.gov/technical/ classification/osd/index.html>.

U.S. Department of Agriculture. 2014. 2012 Census of agriculture. 26 Jan. 2015. <http://www.agcensus.usda.gov/ Publications/2012/Full_Report/ Volume_1,_Chapter_l_US/usvl.pdf $>$.

U.S. Department of Agriculture. 2015. Crop production, 2014 summary. 17 Feb. 2015. <http://www.usda.gov/nass/ PUBS/TODAYRPT/cropan 15.pdf $>$.

U.S. Department of Commerce. 2010. Climatography of the United States 19812010, COOP ID 272174, Durham, NH. 28 Jan. 2015. <http://www.ncdc.noaa. gov/cdo-web/datatools/normals $>$.

Waterer, D. 2010. Evaluation of biodegradable mulches for production of warm-season vegetable crops. Can. J. Plant Sci. 90(5):737-743.

Yencho, G.C., K.V. Pecota, J.R. Schultheis, Z.-P. VanEsbroeck, G.J. Holmes, B.E. Little, A.C. Thornton, and V.-D. Truong. 2008. 'Covington' sweetpotato. HortScience 43:1911-1914. 